\title{
ROUX-EN-Y GASTRIC BYPASS: LIMB LENGTH AND WEIGHT LOSS
}

\author{
Derivação gástrica em Y-de-Roux: comprimento das alças e emagrecimento
}

\author{
Antonio Carlos VALEZI, Antonio César MARSON, Rodrigo Alves MERGUIZO, Fernando Leão COSTA
}

From the Disciplina de Cirurgia Digestiva do Departamento de Cirurgia da Universidade Estadual de Londrina (Service of Digestive Surgery, Department of Surgery, State University of Londrina), Londrina, PR, Brazil

HEADINGS - Roux-en-Y gastric bypass. Limb length. Obesity. Weight loss.
ABSTRACT - Background: Roux-en-Y gastric bypass is a surgical technique widely used in the treatment of obesity. It is unclear, however, if the length of the biliopancreatic and alimentary limb interferes with the magnitude of weight loss. Aim: To evaluate if the length of these limbs is related to the percentage of weight loss one year after surgery. Method: One hundred and twenty obese people underwent surgery between 2009 and 2011. Patients were inserted into four groups: A) biliopancreatic limb with $50 \mathrm{~cm}$ length and alimentary limb with100 $\mathrm{cm}$ length; B) biliopancreatic limb with $50 \mathrm{~cm}$ length and alimentary limb with $150 \mathrm{~cm}$ length; C) biliopancreatic limb with $100 \mathrm{~cm}$ length and alimentary limb with100 cm length; D) biliopancreatic limb with $100 \mathrm{~cm}$ length and alimentary limb with150 cm length. Age, gender, body mass index and the percentage of total weight loss were analyzed. Data were collected preoperatively and one year after surgery. The groups were compared and weight loss compared between groups. Results: The follow-up occurred in $78.3 \%$ of the sample. The composition of the groups was similar, with no statistical significance. The average age was 43 years in groups $A, C$ and $D$ and 42 years in group $B$. The female gender predominated in all groups (about $60 \%$ of the sample). The mean body mass index was $46 \mathrm{~kg} / \mathrm{m}^{2}$ for groups $A, C$ and $D$ and $42 \mathrm{~kg} / \mathrm{m}^{2}$ in group B. The percentage of weight loss was $33 \%$ for group $A$ and $34 \%$ for groups B, C and D. There was no significant difference among groups. Conclusion: Different lengths of the biliopancreatic and alimentary limbs did not affect the percentage of total weight loss.

\section{Correspondence:}

Antonio Carlos Valezi

valezi@sercomtel.com.br

Financial source: none

Conflicts of interest: none

Received for publication: 07/04/2014

Accepted for publication: 15/07/2014

DESCRTORES - Derivação gástrica em Y-de-Roux. Comprimento de alças. Obesidade. Emagrecimento.
RESUMO - Racional: A derivação gástrica em Y-de-Roux é técnica cirúrgica amplamente empregada no tratamento da obesidade. Não está claro, porém, se o comprimento das alças biliopancreática e alimentar interfere na magnitude da perda de peso. Objetivo: Avaliar se o comprimento dessas alças tem relação com a percentagem de perda de peso, um ano após a operação. Método: Cento e vinte obesos foram submetidos à cirurgia entre 2009 e 2011. Eles foram inseridos, por sorteio, em qautro grupos: A) alça biliopancreática de $50 \mathrm{~cm}$ e alimentar de $100 \mathrm{~cm}$; B) alça biliopancreática de $50 \mathrm{~cm}$ e alimentar de $150 \mathrm{~cm}$; C) alça biliopancreática de $100 \mathrm{~cm}$ e alimentar de $100 \mathrm{~cm}$; e D) alça biliopancreática de $100 \mathrm{~cm}$ e alimentar de 150 $\mathrm{cm}$. Analisou-se a idade, o gênero, o índice de massa corpórea e a percentagem de perda do peso total. Os dados foram coletados no pré-operatório e um ano após a operação. Os grupos foram comparados entre si e a perda ponderal comparada entre os grupos. Resultados: 0 acompanhamento ocorreu em $78,3 \%$ da casuística. A composição dos grupos foi semelhante, sem significância estatística. A média de idade foi de 43 anos nos grupos $A, C$ e D e de 42 no grupo B. O gênero feminino predominou em todos os grupos (cerca de $60 \%$ da amostra). $O$ índice de massa corpóreo médio foi de $46 \mathrm{~kg} / \mathrm{m}^{2}$ para os grupos $\mathrm{A}$, C e D e de $42 \mathrm{~kg} / \mathrm{m}^{2}$ no grupo B. A percentagem de perda de peso foi de $33 \%$ para o grupo A e de $34 \%$ para os grupos B, C e D. Sem diferença significante entre os grupos. Conclusão: Diferentes comprimentos das alças biliopancreática e alimentar não interferiram na percentagem de perda do peso total.

INTRODUCTION

$\mathrm{B}$ ariatric surgery is the best treatment for obese patients, being effective method in reducing and maintaining weight in the long time ${ }^{6,17}$. Surgical treatment for obesity causes weight loss and improvement in comorbidities ${ }^{2,18}$. Roux-en-Y gastric bypass (RYGBP) is one of the most performed surgeries for this purpose; however, it is unclear whether technical factors, as the limb length, has relevance in outcomes ${ }^{8,19}$. The length of alimentary and biliopancreatic limbs and their relationship with weight loss determined by RYGBP is controversial, with doubts about the ideal length of these limbs ${ }^{16}$.

The aim of this study is to investigate the relationship between the length of these limbs and the weight loss, comparing different length limbs and the total weight loss one year after surgery.

METHOD

The study was approved by the Ethics and Research Committee of the University Hospital of the State University of Londrina under number 026/2008. The Instrument of Consent was presented and signed by all subjects of study. The authors declare no conflict of interest present in this research. 
One hundred and twenty obese people underwent Roux-en-Y gastric bypass at the University Hospital of the State University of Londrina, PR, Brazil by the same team, from January 2009 to December 2011. This research was designed according to a randomized and prospective study The criteria for inclusion and exclusion of patients in the surgical treatment of obesity program, obeyed the principles of the Brazilian Society for Bariatric and Metabolic Surgery.

For the research, four groups were constituted by draw, immediately before the surgical procedure: group $A$ : biliopancreatic limb length of $50 \mathrm{~cm}$ and alimentary limb length of $100 \mathrm{~cm}$; group B: biliopancreatic limb length of $50 \mathrm{~cm}$ and alimentary limb length of $150 \mathrm{~cm}$; group C: biliopancreatic limb length of $100 \mathrm{~cm}$ and alimentary limb length of $100 \mathrm{~cm}$; group D: biliopancreatic limb length of $100 \mathrm{~cm}$ and alimentary limb length of $150 \mathrm{~cm}$.

The variables were age, gender, body mass index (BMI) and percentage of total weight loss. The following sample was carried out for one year. The groups were compared as to their constitution. The percentage of weight loss was measured at one year postoperatively and compared between groups during this period.

The collected data were stored in Excel and analyzed later through software Statistical Package for the Social Sciences 18.0 (SPSS). Were calculated the mean and standard deviation for quantitative variables and comparison between groups was made by analysis of variance (ANOVA). Categorical variables were compared using the Levene test. For all variables, statistical significance was considered if $p \leq 0: 05$.

\section{RESULTS}

The one year follow up was $78,3 \%$ of the whole sample or 94 patients (24 in group $A ; 25$ in group $B ; 23$ in group C and 22 in group D).

Composition of each group was homogeneous according to age, gender and BMI. There was no statistic significance between them (Table 1 ).

TABLE 1 - Demographic characteristics of the groups

\begin{tabular}{|c|c|c|c|c|c|}
\hline & A & B & C & D & $p$ \\
\hline $\begin{array}{c}\text { Age } \\
\text { (years) }\end{array}$ & $\begin{array}{c}43,97 \\
\mathrm{SD}=10,93\end{array}$ & $\begin{array}{c}42,87 \\
S D=9,53\end{array}$ & $\begin{array}{c}43,13 \\
S D=9,50\end{array}$ & $\begin{array}{c}43,73 \\
S D=10,70\end{array}$ & 0,64 \\
\hline $\begin{array}{c}\text { Female } \\
(\%)\end{array}$ & $\begin{array}{c}19 \\
(63,3)\end{array}$ & $\begin{array}{c}18 \\
(60,00)\end{array}$ & $\begin{array}{c}19 \\
(63,33)\end{array}$ & $\begin{array}{c}17 \\
(56,66)\end{array}$ & \\
\hline $\begin{array}{c}\text { BMI } \\
\left(\mathrm{kg} / \mathrm{m}^{2}\right)^{*}\end{array}$ & $\begin{array}{c}46,9 \\
S D=5,69\end{array}$ & $\begin{array}{c}47,64 \\
S D=5,72\end{array}$ & $\begin{array}{c}46,81 \\
S D=5,50\end{array}$ & $\begin{array}{c}46,10 \\
S D=5,39\end{array}$ & 0,92 \\
\hline
\end{tabular}

*BMI=body mass index; $\mathrm{SD}=$ standard deviation

Group A showed total weight loss of $33.27 \%$ one year after surgery; group B, 34.07\%; and group C and D, 34\% for the same period. When comparing the total weight loss between groups at one year postoperatively, there was no statistical significance (Table 2).

TABLE 2 - Percentage of total weight loss for the groups

\begin{tabular}{|c|c|c|c|c|c|}
\hline $\begin{array}{c}\text { \% weight } \\
\text { loss }\end{array}$ & 33,27 & 34,07 & 34,00 & 34,00 & 0,66 \\
\hline $\begin{array}{c}\text { Standard } \\
\text { deviation }\end{array}$ & DP=2,20 & DP $=2,97$ & DP $=2,16$ & DP $=2,61$ & \\
\hline
\end{tabular}

DISCUSSION

RYGBP was used for this research because it is the most frequent surgery performed in the department for obese people. It's known that RYGBP presents its results, not only due to anatomical factors imposed by the technique - such as decreased food intake by making small gastric pouch or decreased absorption due to the Roux-en-Y reconstruction ${ }^{13}$. Its effects results from neuroendocrine changes that occur because of anatomical changes caused by technical modifications $^{1,9,15}$

It is not clear whether the length of the limbs affects the result of weight loss ${ }^{11}$. It seems rational that the more distal the Roux-en-Y the greater the weight loss. It must make the distinction between long Roux-en-Y and distal Roux-en-Y. The latter is characterized by anastomosis in the distal ileum, with a common limb about $75 \mathrm{~cm}$; in this case there is more significant weight loss, but with a considerable increase in the rate of complications ${ }^{10}$. Longer Roux-en-Y limb presents variation in the length of alimentary and biliopancreatic limbs, but only with extensive common limb4.

This study evaluated the percentage loss of total weight, not of the weight excess. This fact made it easier to collect data and, as far as the entire series was evaluated in the same manner, the adoption of this index did not add bias to the study.

In 1992, Brolin et al. ${ }^{3}$ showed a prospective randomized study comparing weight loss in patients with short Roux-en-Y (biliopancreatic limb with $15 \mathrm{~cm}$ and alimentary with $75 \mathrm{~cm}$ ) and long Roux-en-Y (biliopancreatic limb with $30 \mathrm{~cm}$ and alimentary limb with $150 \mathrm{~cm}$ ) and concluded that those with more distal anastomosis showed more significant weight loss at two years follow up, with no significant nutritional changes. Since then, it was thought to lengthen the $Y$ for the super obese or in cases with failure in weight loss and gastric pouch of normal size.

Sarhan et al. ${ }^{14}$ compared standard and long Roux-en-Y (250 cm biliopancreatic limb) in super-obese and found no difference; they concluded that the length of the limb does not impact weight loss.

Choban and Flancbaum ${ }^{5}$ compared patients with different lengths of alimentary limb $(75 \mathrm{~cm}, 150 \mathrm{~cm}$ and 250 $\mathrm{cm}$ ) and stratified the sample according to BMI. Their results showed significantly more weight loss in the group with 250 $\mathrm{cm} \mathrm{limb}$ and super obese at 18 months postoperatively, this difference disappeared at 24 months follow-up.

Feng et al. ${ }^{7}$ found no statistically significant difference in one year follow-up comparing a group with biliopancreatic limb of $50 \mathrm{~cm}$ and alimentary limb of $100 \mathrm{~cm}$, with another that had biliopancreatic limb of $100 \mathrm{~cm}$ and alimentary of 150 $\mathrm{cm}$ long.

In our country, Ramos ${ }^{12}$ in a retrospective study examined diabetic patients with metabolic syndrome and divided them into three groups: biliopancreatic limb with 50 $\mathrm{cm}$ and alimentary limb with $100 \mathrm{~cm}$; biliopancreatic limb with $50 \mathrm{~cm}$ and alimentary limb with $150 \mathrm{~cm}$ and biliopancreatic limb with $100 \mathrm{~cm}$ and alimentary with $150 \mathrm{~cm}$ long. In a 12 months follow-up, he concluded that the different sizes of limbs had no effect on weight loss and improving metabolic syndrome.

This study, similar to Ramos ${ }^{12}$, showed similar percentage of weight loss in all groups (around 34\%) without statistical significance.

These authors know that this study does not present unpublished results. The findings corroborate survey data that had been shown previously. The series is not small and the authors intend to continue it to evaluate the impact of different measures of limb in diabetic population.

\section{CONCLUSION}

Different lengths of the biliopancreatic and alimentary limbs did not affect the percentage of total weight loss. 


\section{REFERENCES}

1. Anderwald $C H$, Tura $A$, Promintzer-Schifferl $M$, Prager $G$, Stadler M, Ludvik B, Esterbauer H, Bischof MG, Luger A, Pacini G, Krebs M. Alterations in gastrointestinal, endocrine, and metabolic processes after bariatric Roux-en-Y gastric bypass surgery.Diabetes Care. 2012; 35(12):2580-7.

2. Athyros VG, TziomalosK,KaragiannisA, MikhailidisDP.Cardiovascular benefits of bariatric surgery in morbidly obese patients. Obes Rev. 2011; 12(7):515-24.

3. Brolin RE, Kenler HA, Gorman JH, Cody RP. Long-limb gastric bypass in the superobese. A prospective randomized study. Ann Surg. 1992; 215(4):387-95.

4. Brolin RE, LaMarca LB, Kenler HA, Cody RP. Malabsorptive gastric bypass in patients with superobesity. J Gastrointest Surg. 2002; 6(2):195-203.

5. Choban PS, Flancbaum L. The effect of Roux limb lengths on outcome after Roux-en-Y gastric bypass: a prospective, randomized clinical trial. Obes Surg. 2002; 12(4):540-5.

6. Faria GR, Preto JR, Costa-Maia J. Gastric bypass is a cost-saving procedure: results from a comprehensive Markov model. Obes Surg. 2013; 23(4):460-6.

7. Feng JJ, Gagner $M$, Pomp A, Korgaonkar NM, Jacob BP, Chu CA, Voellinger DC, Quinn T, Herron DM, Inabnet WB. Effect of standard vs extended Roux limb length on weight loss outcomes after laparoscopic Roux-en-Y gastric bypass. Surg Endosc. 2003; 17(7):1055-60.

8. Gracia-Solanas JA, Elia M, Aguilella V, Ramirez JM, Martínez J, Bielsa MA, Martínez M. Metabolic syndrome after bariatric surgery. Results depending on the technique performed. Obes Surg. 2011; 21(2):179-85
9. Kao YH, Lo CH, Huang CK. Relationship of bypassed limb length and remission of type 2 diabetes mellitus after Roux-en-Y gastric bypass. Gastrointest Endosc. 2012; 75(4):748-56.

10. Kellum JM, Chikunguwo SM, Maher JW, Wolfe LG, Sugerman HJ. Long-term results of malabsorptive distal Roux-en-Y gastric bypass in superobese patients. Surg Obes Relat Dis. 2011; 7(2):189-93.

11. Miras AD, le Roux CW. Mechanisms underlying weight loss after bariatric surgery. Nat Rev Gastroenterol Hepatol. 2013; 10(10):575-84.

12. Ramos RJ. Efeito das dimensões das derivações intestinais em pacientes obesos diabéticos com síndrome metabólica submetidos ao bypass gástrico. Porto Alegre. Tese [ Mestrado em Medicina e Ciências da Saúde] - Pontifícia Universidade Católica do Rio Grande do Sul;2013.

13. SandovalD. Bariatricsurgeries:beyond restrictionandmalabsorption. Int J Obes. 2011; 35(3):45-9.

14. Sarhan M, Choi JJ, Al Sawwaf M, Murtaza G, Getty JL, Ahmed L. Is weight loss better sustained with long-limb gastric bypass in the super-obese? Obes Surg. 201; 21(9):1337-43.

15. Shah M, Law JH, Micheletto F, Sathananthan M, Dalla Man C, Cobelli C, Rizza RA, Camilleri M, Zinsmeister AR, Vella A. Contribution of endogenous glucagon-like peptide 1 to glucose metabolism after Roux-en-Y gastric bypass. Diabetes. 2014; 63(2):483-93.

16. Stefanidis D, Kuwada TS, Gersin KS. The importance of the length of the limbs for gastric bypass patients--an evidence-based review. Obes Surg. 2011; 21(1):119-24.

17. Stefater MA, Wilson-Pérez HE, Chambers AP, Sandoval DA, Seeley RJ. All bariatric surgeries are not created equal: insights from mechanistic comparisons. Endocr Rev. 2012; 33(4):595-622.

18. Svane MS, Madsbad S. Bariatric surgery - effects on obesity and related co-morbidities. Curr Diabetes Rev. 2014; 10(3):208-14.

19. Vines L, Schiesser M. Gastric bypass: current results and different techniques. Dig Surg. 2014; 31(1):33-9. 